\title{
Peertechz
}

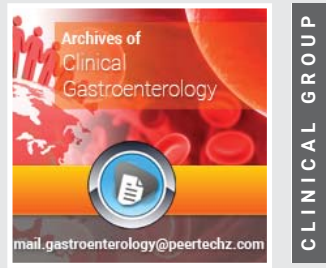

\section{Genetic Polymorphisms of} Vascular Endothelial Growth

\section{Factor (VEGF) -2549 I/D and $+405 \mathrm{G} / \mathrm{C}$ in the susceptibility}

\section{to Gastric Cancer}

\section{Amar chand Bayal, Shehnaz Sultana, Pratibha Nallari and Venkateshwari Ananthapur*}

Institute of Genetics and Hospital for Genetic Diseases, Osmania University, Begumpet,

Hyderabad-500016, Telangana, India
Received: 16 December, 2020

Accepted: 15 January, 2021

Published: 16 January, 2021

*Corresponding author: Dr. Venkateshwari Ananthapur, Institute of Genetics and Hospital for Genetic Diseases, Osmania University, Begumpet, Hyderabad-500016, Telangana, India, Tel: 040 23403681,9948538337;

Email: venkateshwari@yahoo.com

Keywords: Gastric cancer; Polymorphism; VEGF; Haplotype

https://www.peertechz.com

\section{Check for updates}

\section{Abstract}

Objective: Vascular Endothelial Growth Factor (VEGF) plays an important role in tumor angiogenesis. Although several studies revealed on association of VEGF polymorphisms with gastric cancer, still the results are inconclusive. The role of (VEGF) -2549 I/D and $+405 \mathrm{G} / \mathrm{C}$ polymorphisms in gastric cancer of Telangana Population is evaluated in the present study.

Methods: A case control study was carried out on 540 individuals which comprised of 180 Gastric Cancer patients and 360 healthy control subjects. The association of functional single nucleotide polymorphisms (SNPs) of the VEGF gene (-2549 I/D and $+405 \mathrm{G} / \mathrm{C})$ were evaluated by polymerase chain reaction followed by restriction fragment length polymorphism (PCR-RFLP).

Results: VEGF -2549 polymorphism with I/D and I/Igenotypeshoweda threefold higher risk ( $95 \% \mathrm{Cl}=1.75-4.63$ and $95 \% \mathrm{Cl}=1.72-5.78)$ to gastric cancer. A significant association was observed with respect to I allele (AOR=1.67; $95 \% \mathrm{Cl}=1.29-2.15 ; \mathrm{P}=7.641 \mathrm{e}-05)$ while genotypic and allelic frequencies of VEGF $+405 \mathrm{G} / \mathrm{C}$ polymorphism did not show any significant differences in both the groups. A significant increase in the frequency of I-G haplotype in Gastric cancer cases was observed compared to control with an AOR of $2.23(95 \% \mathrm{Cl}=(1.51-3.27) ; \mathrm{P}=0.0001)$.

Conclusion: In conclusion VEGF -2549I/D polymorphism and I-G haplotype conferred significant susceptibility towards gastric cancer, whereas, no such association with respect to $+405 \mathrm{G} / \mathrm{C}$ polymorphism was observed.

\section{Introduction}

Gastric Cancer (GC) of the digestive tract is the third leading cause of carcinoma related deaths worldwide [1]. Gastric cancer is a multifactorial disease associated with various risk factors like tobacco chewing, smoking, alcohol consumption, diet, Helicobacter pylori infection and gastric disorders [2]. Genetic factors play a role in the susceptibility to gastric cancer [3-6], where in Single Nucleotide Polymorphisms (SNPs) of various genes may be causal in the onset of gastric cancer. Angiogenesis is the prerequisite for the growth and progression of tumours with micro invasions. Vascular Endothelial
Growth Factor (VEGF) known to influence tumour-related angiogenesis $[7,8]$. The VEGF gene is located on chromosome 6p12-p21 with eight exons $[9,10]$. Earlier studies have reported an increase in the expression of VEGF to be associated with the grade of angiogenesis and prognosis of various human cancers [11-14]. However, studies investigating the role of VEGF gene polymorphisms in the outcome of gastric cancer are inconclusive. The present study is taken up to elucidate therole of -2549 Insertion/Deletion polymorphism in the promoter region and $+405 \mathrm{G} / \mathrm{C}$ polymorphism in 5' UTR of VEGF gene towards the susceptibility of gastric cancer. 


\section{Materials and methods}

\section{Study subjects}

A case control study was carried out on 180 Gastric Cancers and 360 healthy control subjects with no family history of gastric cancer. Gastric Cancer cases were recruited from the Gastroenterology Department of Osmania General Hospital, Hyderabad. The study included primary Gastric cancer cases which were diagnosed by Upper Gastrointestinal Endoscopy (UGIE) and confirmed by histopathological examination. Lymphoma, other multiple organ malignancies, recurrent gastric tumor and patients with active treatment were excluded from the study. Informed consent was obtained from all the study subjects. The study was approved by Institutional Research Ethics Committee of Institute of Genetics and Hospital for Genetic Diseases. Information on epidemiology such as age, sex, smoking and alcohol consumption was collected using a structured questionnaire.

\section{Genotyping by PCR - RFLP and ARMS PCR}

Total genomic DNA was isolated from peripheral blood leukocytes by the salting out method of Lahiri and Nuernberger [15]. The VEGF -2549I/D polymorphism was genotyped by Polymerase Chain Reaction (PCR) using allele specific primers. Forward primer 5'-GCTGAGAGTGGGGCTGACTAGGTA3'and Reverse primer 5'-GTTTCTGACCTGGCTATTCCAGG3' [16]. The PCR products were separated by agarose gel electrophoresis, wherein a229 bp (I allele with the 18-bp insertion) and $211 \mathrm{bp}$ (D allele with no insertion) fragments were obtained. Similarly, $+405 \mathrm{G} / \mathrm{C}$ polymorphism was genotyped by PCR-RFLP method using forward primer 5'-CAGGTCACTCACTTTGCCCCGGTC-3' and reverse primer 5'-GCTTGCCATTCCCCACTTGAATCG-3'. The obtained PCR product of 204 bp was digested by AvaII restriction enzyme which showed a 185 and 19bp fragment for $\mathrm{G}$ allele whereas, a 204bp fragment representing to $\mathrm{C}$ allele respectively.

\section{Statistical analysis}

Statistical significance of the differences in the genotype frequencies between the gastric cancer cases and controls was determined by multiple logistic regression under different genetic models (i.e.co-dominant, recessive, dominant and log-additive) of inheritance using $\mathrm{R}$ version 3.3.1 and $\mathrm{R}$ package "SNPassoc." The Adjusted Odds Ratios (AORs) and corresponding 95\% Confidence Intervals (CIs) were obtained after controlling confounding factors including age, gender, smoking, tobacco chewing and alcohol consumption. The Akaike Information Criterion (AIC) was adopted to determine the best-fit genetic model. The pvalues obtained from MLR were adjusted for false discovery rate of BH method [17]. The observed genotype frequencies in the controls and cases were tested for Hardy- Weinberg Equilibrium (HWE) to ensure the independent distribution of the alleles in the sample and to rule out any genotyping errors. Haplotype analysis was performed using Haploview (version 4.2) softwareto understand the nature of the cosegregation of polymorphisms ingastric cancer. Most frequent haplotype was selected as reference category and rare haplotype groups whose frequency $<0.001$ were eliminated from the study. The association analysis of haplotypes was shown as Odds Ratios (OR) and 95\%CI. The adjusted odds ratio was calculated for each haplotype to know the true association by eliminating the effects of covariates (i.e. age, sex, and addictions). All ' $p$ ' values were two-tailed and the significance level at $5 \%$ was taken into consideration.

\section{Results}

A total of 540 subjects comprising of 180 Gastric cancer patients and 360 controls were included in the study. Demographic data of gastric cancer patients and control subjects are given in Table 1 . The patient group comprised of $128(71.1 \%)$ males and $52(28.9 \%)$ females while the control group constituted $222(61.7 \%)$ males and 138 (38.3\%) females. A 1.9-foldrisk for gastric cancer in males was observed. The study group was subdivided into 3 age groups early $(\leq 45$ years), middle (46-60 years) and late ( $>60$ years). Increased risk of gastric cancer was observed in middle age group (AOR $(95 \% \mathrm{CI})=1.71(1.09-2.68) ; \mathrm{p}=0.020)$ followed by late onset $(\mathrm{AOR}(95 \% \mathrm{CI})=2.11(1.29-3.47) ; \mathrm{p}=0.003)$ age groups. The percentage of smokers in gastric cancer was $51.1 \%$, and $26.4 \%$ in control group revealing a 2.01-fold increased risk to gastric cancer compared to non-smokers $($ AOR $(95 \% \mathrm{CI})=2.01(1.23-$ $3.29) ; \mathrm{p}=0.005) \cdot 36.1 \%$ of tobacco chewers were afflicted with gastric cancer compared to controls of $21.4 \%$, showing a 2.12 fold increased risk $(\mathrm{AOR}(95 \% \mathrm{CI})=2.12(1.39-3.22) ; \mathrm{p}=<0.000)$. The percentage of alcohol consumers in gastric cancer group was $52.2 \%$ whereas in control subjects it was $28.9 \%$ showing 1.79-fold risk for alcoholics compared to non-alcoholics (AOR $(95 \% \mathrm{CI})=1.76(1.08-2.86) ; \mathrm{p}=<0.023)$.

Distribution of genotypes and allele frequencies of VEGF -2549I/D polymorphism in gastric cancer patients and control group are depicted in Table 2 . The genotype frequencies of $\mathrm{D} / \mathrm{D}, \mathrm{I} / \mathrm{D}$ and $\mathrm{I} / \mathrm{I}$ were $34.1 \%, 59.4 \%$ and $21.7 \%$ in patients while $36.7 \%, 49.2 \%$ and $14.2 \%$ in controls respectively. The frequencies of D and I alleles were 0.49 vs. 0.61 in gastric cancer and 0.51 vs. 0.39 in the control subjects. The distribution of genotypes and alleles differed significantly between the patients and controls. Further logistic regression analysis also corroborated that patients with I/D and I/I genotype had a 2.84 -fold higher risk $(95 \% \mathrm{CI}=1.75-4.63)$ and $3.15-$ fold $(95 \% \mathrm{CI}=1.72-5.78)$ to gastric cancer compared with $\mathrm{D} / \mathrm{D}$ genotype, with the risk being significant for I allele genotypes $(\mathrm{AOR}=1.67 ; 95 \% \mathrm{CI}=1.29-2.15 ; \mathrm{P}=7.641 \mathrm{e}-05)$. Based on the values of Akaike information criterion (AIC), a dominant model with least AIC value was found to be best genotypic model indicating about 2.92 -fold $(95 \% \mathrm{CI}=1.83-4.67, \mathrm{P}=3.76 \mathrm{e}-05)$ increased risk of I allele carriers (I/D $+\mathrm{I} / \mathrm{I})$ to gastric cancer. The genotype distribution of VEGF -2549I/D polymorphism showed significant deviation from Hardy Weinberg equilibrium (HWE) in the patient group $(\mathrm{P}=0.01663)$ but not in controls $(\mathrm{P}=0.578624)$ which also supports the possible association and hence deviation from Hardy Weinberg equilibrium with gastric cancer. Genotype and allelic frequencies did not differ between the case and control groups with respect to $+405 \mathrm{G} / \mathrm{C}$ genotypes (Table 3).

Citation: Bayal AC, Sultana S, Nallari P, Ananthapur V (2021) Genetic Polymorphisms of Vascular Endothelial Growth Factor (VEGF) -2549 I/D and +405G/C in the susceptibility to Gastric Cancer. Arch Clin Gastroenterol 7(1): 001-006. DOI: https://dx.doi.org/10.17352/2455-2283.000088 
Table 1: Distribution of Epidemiological variables in Gastric Cancer patients and controls.

\begin{tabular}{|c|c|c|c|c|c|}
\hline \multicolumn{2}{|c|}{ Epidemiological characteristics } & $\begin{array}{c}\text { Control } \\
(\mathrm{N}=360) \\
n(\%)\end{array}$ & $\begin{array}{c}\text { Gastric } \\
\text { Cancer } \\
(\mathrm{N}=180) \\
n(\%)\end{array}$ & $\begin{array}{c}\text { Crude OR } \\
\text { (95\%Cl); } \\
\text { P-value }\end{array}$ & $\begin{array}{c}\text { AOR }(95 \% \mathrm{Cl}) \\
\text { P-value }\end{array}$ \\
\hline \multirow{2}{*}{ Sex } & Female & $138(38.3)$ & $52(28.9)$ & 1.00 (Refr.) & -- \\
\hline & Male & $222(61.7)$ & $128(71.1)$ & $1.53(1.04-2.25) ; 0.031^{*}$ & $1.04(0.67-1.62) ; 0.866$ \\
\hline \multicolumn{2}{|c|}{ Age (Mean \pm SD) } & $49.37 \pm 12.08$ & $53.23 \pm 11.78$ & -- & -- \\
\hline \multirow{3}{*}{$\begin{array}{l}\text { Age } \\
\text { Group }\end{array}$} & $\leq 45$ yrs. & $144(40.0)$ & $50(27.8)$ & 1.00 (Refr.) & 1.00 (Refr.) \\
\hline & $46-60$ yrs. & $130(36.1)$ & $76(42.2)$ & $1.68(1.10-2.58) ; 0.017^{\star}$ & $1.71(1.09-2.68) ; 0.020^{\star}$ \\
\hline & $>60$ yrs. & $86(23.9)$ & $54(30.0)$ & $1.81(1.13-2.89) ; 0.013^{*}$ & 2.11 (1.29-3.47); 0.003* \\
\hline \multirow[t]{2}{*}{ Smoking } & $\begin{array}{c}\text { Non } \\
\text { smokers }\end{array}$ & $265(73.6)$ & $88(48.9)$ & 1.00 (Refr.) & 1.00 (Refr.) \\
\hline & Smokers & $95(26.4)$ & $92(51.1)$ & $2.92(2.01-4.24) ;<0.0001^{*}$ & $2.01(1.23-3.29) ; 0.005^{\star}$ \\
\hline \multirow{2}{*}{ Tobacco chewing } & No & $283(78.6)$ & 115 (63.9) & 1.00 (Refr.) & 1.00 (Refr.) \\
\hline & Yes & $77(21.4)$ & $65(36.1)$ & $2.08(1.40-3.08) ;<0.0001^{*}$ & $2.12(1.39-3.22) ;<0.000 *$ \\
\hline \multirow{2}{*}{ Alcoholism } & Non-alcoholics & $256(71.1)$ & $86(47.8)$ & 1.00 (Refr.) & 1.00 (Refr.) \\
\hline & Alcoholics & $104(28.9)$ & $94(52.2)$ & $2.69(1.86-3.89) ;<0.0001^{*}$ & 1.76 (1.08-2.86); 0.023* \\
\hline
\end{tabular}

Table 2: Distribution of genotypes and allele frequencies of Vascular Endothelial Growth Factor (VEGF) -2549 Insertion Deletion polymorphism in Gastric Cancer patients and Control subjects.

\begin{tabular}{|c|c|c|c|c|c|c|c|}
\hline Model & Genotype & $\begin{array}{c}\text { Control } \\
\text { n (\%) }\end{array}$ & $\begin{array}{c}\text { Gastric } \\
\text { Cancer } \\
\text { n (\%) }\end{array}$ & AOR $(95 \% \mathrm{Cl})$ & P-value & Adjusted P-value & AIC \\
\hline \multirow{3}{*}{$\begin{array}{c}\text { Co } \\
\text { dominant }\end{array}$} & $\mathrm{D} / \mathrm{D}$ & $132(36.7)$ & $34(18.9)$ & 1.00 (Refr.) & \multirow{3}{*}{$1.431 \mathrm{e}-05^{\star}$} & \multirow{3}{*}{$0.000107^{\star}$} & \multirow{3}{*}{619.8} \\
\hline & I/D & $177(49.2)$ & $107(59.4)$ & $2.84(1.75-4.63)$ & & & \\
\hline & $1 / 1$ & $51(14.2)$ & 39 (21.7) & $3.15(1.72-5.78)$ & & & \\
\hline \multirow{2}{*}{ Dominant } & $\mathrm{D} / \mathrm{D}$ & $132(36.7)$ & 34 (18.9) & 1.00 (Refr.) & \multirow{2}{*}{$2.509 \mathrm{e}-06^{\star}$} & \multirow{2}{*}{$3.76 \mathrm{e}-05^{\star}$} & \multirow{2}{*}{618.0} \\
\hline & I/D-I/I & $228(63.3)$ & $146(81.1)$ & $2.92(1.83-4.67)$ & & & \\
\hline \multirow{2}{*}{ Recessive } & D/D-I/D & $309(85.8)$ & $141(78.3)$ & 1.00 (Refr.) & \multirow{2}{*}{0.0763} & \multirow{2}{*}{0.104049} & \multirow{2}{*}{637.0} \\
\hline & $1 / 1$ & $51(14.2)$ & $39(21.7)$ & $1.57(0.96-2.57)$ & & & \\
\hline \multirow{2}{*}{$\begin{array}{c}\text { Over- } \\
\text { dominant }\end{array}$} & D/D-I/I & $183(50.8)$ & $73(40.6)$ & 1.00 (Refr.) & \multirow{2}{*}{$0.003883^{\star}$} & \multirow{2}{*}{0.0581984} & \multirow{2}{*}{631.8} \\
\hline & I/D & $177(49.2)$ & $107(59.4)$ & $1.78(1.20-2.64)$ & & & \\
\hline $\begin{array}{l}\text { Log- } \\
\text { additive }\end{array}$ & -- & -- & -- & $1.83(1.36-2.45)$ & $3.825 \mathrm{e}-05^{\star}$ & $0.000191 *$ & 623.2 \\
\hline \multirow[b]{2}{*}{ Allelic } & $\mathrm{D}$ & $441(0.61)$ & $175(0.49)$ & 1.00 (Refr.) & \multirow{2}{*}{$7.641 e-05^{\star}$} & \multirow{2}{*}{--} & \multirow{2}{*}{-} \\
\hline & 1 & $279(0.39)$ & $185(0.51)$ & $1.67(1.29-2.15)$ & & & \\
\hline
\end{tabular}

Adjusted for: age, sex and addictions; AOR: Adjusted Odds Ratio; Adjusted P-value: FDR adjusted P-value; AIC: Akaike Information Criterion; *: P <0.05 at $5 \%$ level of significance.

Codominant AOR 1 I/D vs. D/D; Codominant AOR2: I/I vs. D/D; Dominant AOR: I/D-I/I vs. D/D; Recessive AOR: I/I vs. D/D-I/D; Log-additive AOR: D/D-0, I/D-1, I/I- 2.

To evaluate the combined effect of VEGF polymorphisms (-2549I/D and +405G/C) in the suspectability to GC, haplotype analysis was performed using SNPSTAT tool. Four haplotype groups were observed (Table 4). Haplotype D-G was the most frequently found among controls and cases thus considered as a reference group. A significant increase in the frequencyof I-Ghaplotype in gastric cancer cases was observed compared to control (0.42 vs. 0.28 ) with an AOR of 2.23 (95\%CI= (1.51-3.27); $\mathrm{P}=0.0001)$. Global haplotype score test deviated significantly among controls and cases (Global haplotype $\mathrm{P}=0.00012$ ). As there are no previous reports on haplotype association of the VEGF (-2549I/D and +405G/C) polymorphisms with gastric cancer, a comparative analysis was notpossible to strengthen the above associations.

\section{Discussion}

Gastric cancer, a disease of heterogeneous origin involving several factors such as genetic, environmental, immune, diet, infections and inflammation may lead to disturbances in the signalling pathways related to growth and regulation of gastric tumours due to the influence of gene/s variation $[18,19]$. Genetic variations and disease susceptibility play an important role in the pathogenesis of gastric cancer [20-22]. Tumour growth, relapse and metastasis turns on the "angiogenic switch" to induce tumour growth to a size greater than 1-2 $\mathrm{mm}$ which is regulated by angiogenic activators and inhibitors [23]. Hypoxia triggers tumour angiogenesis and which further activates the expression of Hypoxia-Inducible Factor-1 (HIF1) in the expression of various other proangiogenic factors such as Vascular Endothelial Growth Factor (VEGF) and Vascular Endothelial Growth Factor Receptor (VEGFR) in micro angiogenesis and invasion [24,25].

Cancer cells in the growth phase encourage the new blood vessels formation by secreting VEGF and VEGFR into the Tumour Micro Environment (TME) surrounding and the secreted VEGF binds to VEGFR on the Endothelial Cells (ECs) outer surface. VEGF signalling pathway activates ECs and induces the growth, survival, vascular permeability and migration of ECs to encourage tumour angiogenesis [26]. The 
Table 3: Distribution of genotypes and allele frequencies of Vascular Endothelial Growth Factor (VEGF) 405G/C polymorphism in Gastric Cancer patients and Control subjects.

\begin{tabular}{|c|c|c|c|c|c|c|c|}
\hline Model & Genotype & $\begin{array}{c}\text { Control } \\
\text { n (\%) }\end{array}$ & $\begin{array}{c}\text { Gastric } \\
\text { Cancer } \\
\text { n (\%) }\end{array}$ & AOR $(95 \% \mathrm{Cl})$ & P-value & Adjusted P-value & AIC \\
\hline \multirow{3}{*}{$\begin{array}{c}\text { Co- } \\
\text { dominant }\end{array}$} & $\mathrm{G} / \mathrm{G}$ & $172(47.8)$ & $100(55.6)$ & 1.00 (Refr.) & \multirow{3}{*}{0.14261} & \multirow{3}{*}{0.152797} & \multirow{3}{*}{638.2} \\
\hline & $\mathrm{G} / \mathrm{C}$ & $160(44.4)$ & $64(35.6)$ & $0.68(0.45-1.02)$ & & & \\
\hline & $\mathrm{C} / \mathrm{C}$ & $28(7.8)$ & $16(8.9)$ & $1.05(0.52-2.12)$ & & & \\
\hline \multirow{2}{*}{ Dominant } & $\mathrm{G} / \mathrm{G}$ & $172(47.8)$ & $100(55.6)$ & 1.00 (Refr.) & \multirow{2}{*}{0.11453} & \multirow{2}{*}{0.171793} & \multirow{2}{*}{637.6} \\
\hline & $\mathrm{G} / \mathrm{C}-\mathrm{C} / \mathrm{C}$ & $188(52.2)$ & $80(44.4)$ & $0.73(0.50-1.08)$ & & & \\
\hline \multirow{2}{*}{ Recessive } & G/G-G/C & $332(92.2)$ & $164(91.1)$ & 1.00 (Refr.) & \multirow{2}{*}{0.54073} & \multirow{2}{*}{0.540733} & \multirow{2}{*}{639.7} \\
\hline & $\mathrm{C} / \mathrm{C}$ & $28(7.8)$ & $16(8.9)$ & $1.24(0.63-2.45)$ & & & \\
\hline \multirow{2}{*}{ Over-dominant } & $\mathrm{G} / \mathrm{G}-\mathrm{C} / \mathrm{C}$ & $200(55.6)$ & $116(64.4)$ & 1.00 (Refr.) & \multirow{2}{*}{0.05112} & \multirow{2}{*}{0.06982} & \multirow{2}{*}{636.2} \\
\hline & $\mathrm{G} / \mathrm{C}$ & $160(44.4)$ & $64(35.6)$ & $0.67(0.45-1.00)$ & & & \\
\hline $\begin{array}{l}\text { Log- } \\
\text { additive }\end{array}$ & -- & -- & -- & $0.86(0.64-1.17)$ & 0.33501 & 0.364585 & 639.2 \\
\hline \multirow{2}{*}{ Allelic } & G & $504(0.70)$ & $264(0.73)$ & 1.00 (Refr.) & \multirow{2}{*}{0.2546} & \multirow{2}{*}{---} & \multirow{2}{*}{--} \\
\hline & $\mathrm{C}$ & $216(0.30$ & $96(0.27)$ & $0.85(0.64-1.13)$ & & & \\
\hline
\end{tabular}

Adjusted for: age, sex and addictions; AOR: Adjusted odds ratio, Adjusted P-value: FDR adjusted P-value. AIC: Akaike Information Criterion; *: $P<0.05$ at $5 \%$ level of significance.

Codominant AOR': G/C vs. G/G; Codominant AOR²: C/C vs. G/G; Dominant AOR: G/C-C/C vs. G/G; Recessive AOR: C/C vs. G/G-G/C; Log-additive AOR: G/G-0, G/C-1, C/C- 2.

Table 4: Haplotype frequencies distribution and association of VEGF polymorphisms with Gastric Cancer.

\begin{tabular}{|c|c|c|c|c|c|c|}
\hline $\begin{array}{c}\text { VEGF } \\
-2549 \text { ID }\end{array}$ & VEGF 405G/C & Total & Control & GC & OR (95\%Cl) & P-value \\
\hline D & G & 0.3773 & 0.412 & 0.3119 & 1.00 & -- \\
\hline I & G & 0.3338 & 0.288 & 0.4214 & $2.23(1.51-3.27)$ & $1 \mathrm{e}-04$ \\
\hline D & C & 0.1931 & 0.2005 & 0.1742 & $1.21(0.76-1.92)$ & 0.42 \\
\hline I & C & 0.0958 & 0.0995 & 0.0924 & $1.29(0.73-2.31)$ & 0.38 \\
\hline
\end{tabular}

Global haplotype association P-value: 0.00012*

proangiogenic abilities of gastric cancer cells secrete angiogenic cytokines and stimulate ECs to support their own growth in an autocrine manner. VEGF acts as a key mediator of angiogenesis and micro invasion in cancers and is also involved in cellular processes which can be influence by the functional polymorphic variants of the gene [27]. VEGF gene polymorphism may alter VEGF production and activity, thereby causing inter-individual differences in the angiogenesis, lymph and vascular and lymphatic tumor spread. According to Ohta, et al. peripheral blood plasma VEGF-A level was reported to be increased in patients with venous invasion and correlated with lymph node metastasis and reported as a sensitive marker for the progression of gastric cancer [28]. Similarly, VEGF +1612G >A gene polymorphism was found to be associated with gastric cancer in Chinese and Japanese population [29,30]. VEGF $-2578 \mathrm{C}>\mathrm{A}$ and $-634 \mathrm{G}>\mathrm{C}$ polymorphisms were associated with larger tumor size, poor differentiation, advanced stage of gastric cancer in Greek population [31]. The insertion/deletion (I/D) polymorphism in the promoter region of VEGF at the position - 2549 relative to the translation start site has been linked to an altered transcriptional activity [32].

This is the first study reporting an association of VEGF -2549 I/D polymorphism with gastric cancer. The findings of the present study are in concordance with the earlier reports that I allele and I allele carrier genotypes (i.e. I/D, I/I) were associated with breast cancer of North Indian origin [33]. The I/D genotype was also being reported to be at greater risk to prostate cancer in a study from North India [34]. Further VEGF
$+405 \mathrm{G} / \mathrm{C}$ polymorphism in the 5' UTR has a significant effect on VEGF expression. Similarly, a study on association of $+405 \mathrm{C} / \mathrm{C}$ genotype with poor tumor differentiation and lymph node metastasis in gastric cancer was reported [21]. VEGF $+405 \mathrm{C}$ allele reduces binding of the transcription factor myeloid zinc finger protein MZF1, which then subsequently reduces the gene expression [35-37]. According to a study 405C/C genotype was associatedwith larger tumor size, metastasis and advanced stages of gastric cancer [31]. However, in the present study no such association between $+405 \mathrm{G} / \mathrm{C}$ polymorphism and gastric cancer was observed.

Further haplotype analysis showed increased frequency of I-G haplotype in gastric cancer compared to controls. Study carried out by chae, et al. on VEGF gene polymorphisms $(-460 \mathrm{~T}>\mathrm{C},+405 \mathrm{G}>\mathrm{C}$, and 936C > T) showed TCT haplotype was associated with decreased susceptibility to gastric cancer [38]. Kim, et al. reported association of CACC haplotype with worse survival compared to TGGC haplotype in patients with surgically resected gastric cancer [22]. Penelope, et al. showed CGC haplotype of combined 460T/C, 405G/C, and 936C/T VEGF polymorphisms associated with reduced overall survival and had a potential prognostic significance in oesophageal cancer [39].

\section{Conclusion}

In conclusion VEGF -2549I/D polymorphism and I-G haplotype has shown a significant association and susceptibility towards gastric cancer which throws a light on the molecular mechanism of tumour angiogenesis in gastric cancer and helps in developing a novel antiangiogenic strategy. This is the first report of the VEGF polymorphism reflecting the synergistic action of two SNPs which seem to exert influence on the expression of VEGF.

\section{References}

1. Torre LA, Bray F, Siegel RL, Ferlay J, Lortet-Tieulent J, et al. (2015) Global cancer statistics 2012. CA Cancer J Clin 65: 87-108. Link: http://bit.ly/3imLFeY 
2. Woo HD, Lee J, Choi IJ, Kim CG, Lee JY, et al. (2014) Dietary flavonoids and gastric cancer risk in a Korean population. Nutrients 6: 4961-4973. Link: http://bit.ly/3bH6S1N

3. Chang J, Wei LX, Miao XP, Yu DK, Tan W, et al. (2015) Two novel variants on $13 q 22.1$ are associated with risk of esophageal squamous cell carcinoma. Cancer Epidemiol Biomarkers Prev 24: 1774-1780. Link: http://bit.ly/38L5k55

4. Bush WS, Moore JH (2012) Genome-wide association studies. PloS Comput Biol 8: e1002822.

5. Jin GF, Ma HX, Wu C, Dai JC, Zhang RY, et al. (2012) Genetic variants at 6p21.1 and 7p15.3 are associated with risk of multiple cancers in Han Chinese. Am J Hum Genet 91: 928-934. Link: http://bit.ly/38JpEU9

6. Hu N, Wang ZM, Song X, Wei LX, Kim BS, et al. (2016) Genome-wide association study of gastric adenocarcinoma in Asia: a comparison of associations between cardia and non-cardia tumours. Gut 65: 1611-1618. Link: http://bit.ly/3qqMiqn

7. Yancopoule GD, Davis S, Gale NW, Rudge JS, Wiegand SJ, et al. (2000) Vascular-specific growth factors and blood vessel formation. Nature 407: 242 248. Link: http://bit.ly/3oNxcuL

8. Carmeliet P, Jain RK (2000) Angiogenesis in cancer and other disease. Nature 407: 249-257. Link: http://bit.ly/3bH76WH

9. Mattei MG, Borg JP, Rosnet O, Marmé D, Birnbaum D (1996) Assignment of vascular endothelial growth factor (VEGF) and placenta growth factor (PIGF) genes to human chromosome 6p12-p21 and 14q24-q31 regions, respectively. Genomics 31: 168-169. Link: http://bit.ly/38J2m0M

10. Tischer E, Mitchell R, Hartman T, Silva M, Gospodarowicz D, et al. (1991) The human gene for vascular endothelial growth factor: multiple protein forms are encoded through alternative exon splicing. J Biol Chem 266: 11947-11954. Link: http://bit.ly/3qnzPE1

11. Toi M, Matsumoto $T$, Bando $H$ (2001) Vascular endothelial growth factor: its prognostic, predictive, and therapeutic implications. Lancet Oncol 2: 667-673. Link: http://bit.ly/2XKD4Je

12. Masuya D, Huang C-H, Liu D, Kameyama K, Hayashi E, et al. (2001) The intratumoral expression of vascular endothelial growth factor and interleukin-8 asscociated with angiogenesis in nonsmall cell lung carcinoma patients. Cancer 92: 2628-2638. Link: http://bit.ly/3oMmm8q

13. Fontanini G, Faviana P, Lucchi M, Boldrini L, Mussi A, et al. (2002) A high vascular count and overexpression of vascular growth factor are associated with unfavorable prognosis in operated small cell lung cancer. $\mathrm{Br} \mathrm{J}$ Cancer 86 558-563. Link: http://bit.ly/35FX8ku

14. Nishida N, Yano H, Komai K, Nishida T, Kamura T, et al. (2004) Vascular endothelial growth factor $\mathrm{C}$ and vascular endothelial growth factor receptor 2 are related closely to the prognosis of patients with ovarian carcinoma. Cancer 101: 1364-1374. Link: http://bit.ly/3nTRLVn

15. Lahiri DK, Nurnberger JI (1991) A rapid non-enzymatic method for the preparation of HMW DNA from blood for RFLP studies. Nucleic Acids Res 19 5444. Link: http://bit.ly/3bJMEV4

16. Buraczynska M, Ksiazek P, Baranowicz-Gaszczyk I, Jozwiak L (2007) Association of the VEGF gene polymorphism with diabetic retinopathy in type 2 diabetes patients. Nephrol Dial Transplant 22: 827-832. Link: http://bit.ly/3oSkqvi

17. Benjamini Y, Hochberg Y (1995) Controlling the false discovery rate: a practical and powerful approach to multiple testing. Journal of the Royal Statistical Society. Series B (Methodological) 57: 289-300. Link: https://bit.ly/35I1BDk

18. Frazer KA, Murray SS, Schork NJ, Topol EJ (2009) Human genetic variation and its contribution to complex traits. Nat Rev Genet 10: 241-251. Link: http://bit.ly/3qgnZeO
19. Dong LM, Potter JD, White E, Ulrich CM, Cardon LR, et al. (2008) Genetic susceptibility to cancer: the role of polymorphisms in candidate genes. JAMA 299: $2423-2436$

20. Ke Q, Liang J, Wang LN, Hu ZB, Jin GF, et al. (2008) Potentially functional polymorphisms of the vascular endothelial growth factor gene and risk of gastric cancer. Mol Carcinog 47: 647-651. Link: http://bit.ly/39Aa8sZ

21. Al-Moundhri MS, Al-Nabhani M, Burney IA, Al-Farsi AA, Al-Bahrani B (2009) Gastric cancer risk predisposition and prognostic significance of vascular endothelial growth factor (VEGF) gene polymorphisms--a casecontrol study in an Omani population. Mol Carcinog 48: 1170-1176. Link: http://bit.ly/2MVYdOz

22. Kim JG, Sohn SK, Chae YS, Cho YY, Bae HI, et al. (2007) Vascular endothelial growth factor gene polymorphisms associated with prognosis for patients with gastric cancer. Ann Oncol 18: 1030-1036. Link: http://bit.ly/2Lr1tBq

23. Bergers G, Benjamin LE (2003) Tumorigenesis and the angiogenic switch. Nat Rev Cancer 3: 401-410. Link: http://bit.ly/3nM90Yg

24. Bottaro DP, Liotta LA (2003) Cancer: Out of air is not out of action. Nature 423 593-595. Link: http://bit.ly/38lue58

25. Harris AL (2002) Hypoxia--a key regulatory factor in tumour growth. Nat Rev Cancer 2: 38-47. Link: http://bit.ly/38II3BU

26. Bose S, Deininger M, Gora-Tybor J, Goldman JM, Melo JV (1998) The presence of typical and atypical BCRABL fusion genes in leukocytes of normal individuals: biologic significance and implications for the assessment of minimal residual disease. Blood 92: 3362-3367. Link: http://bit.ly/38MDaGA

27. Wu GY, Hasenberg T, Magdeburg R, Bonninghoff R, Sturm JW, et al. (2009) Association between EGF, TGF-beta1, VEGF gene polymorphism and colorectal cancer. World J Surg 33: 124-129. Link: http://bit.ly/3bDazWI

28. Ohta M, Konno H, Tanaka T, Kamiya K, Baba M, et al. (2003) The significance of circulating vascular endothelial growth factor (VEGF) protein in gastric cancer. Cancer Lett 192: 215-225. Link: http://bit.ly/2LD3wCd

29. Zhou Y, Li N, Zhuang W, Wu X (2011) Vascular endothelial growth factor (VEGF) gene polymorphisms and gastric cancer risk in a Chinese Han population. Mol Carcinog 50: 184-188. Link: http://bit.ly/3suzK36

30. Tahara T, Shibata T, Nakamura M, Yamashita H, Yoshioka D, et al. (2009) Effect of polymorphisms in the 3' untranslated region (3'-UTR) of vascular endothelial growth factor gene on gastric cancer and peptic ulcer diseases in Japan. Mol Carcinog 48: 1030-1037. Link: http://bit.ly/39BDzeb

31. Tzanakis N, Gazouli M, Rallis G, Giannopoulos G, Papaconstantinou I, et al. (2006) Vascular endothelial growth factor polymorphisms in gastric cancer development, prognosis, and survival. J Surg Oncol 94: 624-630. Link: http://bit.ly/3oLWt8x

32. Yang B, Cross DF, Ollerenshaw M, Millward BA, Demaine AG (2003) Polymorphisms of the vascular endothelial growth factor and susceptibility to diabetic microvascular complications in patients with type 1 diabetes mellitus. J Diabetes Complications 17: 1-6. Link: http://bit.ly/3nMbGFA

33. Kapahi R, Manjari M, Uppal MS, Singh NR, Sambyal V, et al. (2013) Association of -2549 Insertion/Deletion Polymorphism of Vascular Endothelial Growth Factor with Breast Cancer in North Indian Patients. Genet Test Mol Biomarkers 17: 242-248. Link: http://bit.ly/39rXpIM

34. George GP, Mittal RD (2011) Association of polymorphic variants of vascular endothelial growth factor (VEGF) gene in relation to risk and androgen therapy response in prostate cancer patients of North India. Link: http://bit.ly/3bH8rNc

35. Watson CJ, Webb NJ, Bottomley MJ, Brenchley PE (2000) Identification of polymorphisms within the vascular endothelial growth factor (VEGF) gene: correlation with variation in VEGF protein production. Cytokine 12: 1232-1235 Link: http://bit.ly/3sr8677

Citation: Bayal AC, Sultana S, Nallari P, Ananthapur V (2021) Genetic Polymorphisms of Vascular Endothelial Growth Factor (VEGF) -2549 I/D and +405G/C in the susceptibility to Gastric Cancer. Arch Clin Gastroenterol 7(1): 001-006. DOI: https://dx.doi.org/10.17352/2455-2283.000088 
36. Hussein A, Askar E, Elsaeid M, Schaefer F (2010) Functional polymorphisms in transforming growth factor-beta-1 (TGF $\beta-1)$ and vascular endothelial growth factor (VEGF) genes modify risk of renal parenchymal scarring following childhood urinary tract infection. Nephrology Dialysis Transplantation 25: 779785. Link: https://bit.ly/3nIP5tn

37. Young HS, Summers AM, Bhushan M, Brenchley PE, Griffiths CE (2004) Singlenucleotide polymorphisms of vascular endothelial growth factor in psoriasis of early onset. J Invest Dermatol 122: 209-215. Link: http://bit.ly/38MDBAI
38. Chae YS, Kim JG, Sohn SK, Cho YY, Moon JH, et al. (2006) Investigation of vascular endothelial growth factor gene polymorphisms and its association with clinicopathologic characteristics in gastric cancer. Oncology 71: 266-272. Link: http://bit.ly/3bHsJGc

39. Bradbury PA, Zhai R, Ma C, Xu W, Hopkins J, et al. (2009) Vascular Endothelial Growth Factor Polymorphisms and Esophageal Cancer Prognosis. Clin Cancer Res 15: 4680-4685. Link: http://bit.ly/38IK53C

\section{Discover a bigger Impact and Visibility of your article publication with}

\section{Peertechz Publications}

\section{Highlights}

* Signatory publisher of ORCID

- Signatory Publisher of DORA (San Francisco Declaration on Research Assessment)

* Articles archived in worlds' renowned service providers such as Portico, CNKI, AGRIS, TDNet, Base (Bielefeld University Library), CrossRef, Scilit, J-Gate etc.

* Journals indexed in ICMJE, SHERPA/ROMEO, Google Scholar etc.

* OAI-PMH (Open Archives Initiative Protocol for Metadata Harvesting)

* Dedicated Editorial Board for every journal

* Accurate and rapid peer-review process

* Increased citations of published articles through promotions

* Reduced timeline for article publication

Submit your articles and experience a new surge in publication services (https://www.peertechz.com/submission).

Peertechz journals wishes everlasting success in your every endeavours.

Copyright: @ 2021 Bayal AC, et al. This is an open-access article distributed under the terms of the Creative Commons Attribution License, which permits unrestricted use, distribution, and r eproduction in any medium, provided the original author and source are credited.

Citation: Bayal AC, Sultana S, Nallari P, Ananthapur V (2021) Genetic Polymorphisms of Vascular Endothelial Growth Factor (VEGF) -2549 I/D and +405G/C in the susceptibility to Gastric Cancer. Arch Clin Gastroenterol 7(1): 001-006. DOI: https://dx.doi.org/10.17352/2455-2283.000088 